\title{
Genotoxicity of Plant Mediated Synthesis of Copper Nanoparticles Evaluated Using In Vitro Mammalian Cell Micronucleus Test
}

\author{
Margi H. Patel ${ }^{1}$ (D), Karishma D. Vashi ${ }^{2}$ (D), Farida P. Minocheherhomji ${ }^{1}$ (D), Rajendra Nagnae ${ }^{2}$ (D) \\ ${ }^{1}$ Department of Microbiology, B.P.Baria Science Institute, Sayaji Road, Navsari - 396445, Gujarat, India. \\ ${ }^{2}$ Department of Toxicology, Jai Research Foundation, Nr. Daman Ganga Bridge, Valvad Gujarat, India. \\ Correspondence Author: Margi H. Patel \\ E-mail: margipatel1411@gmail.com
}

Received: $27.12 .2019 \quad$ Accepted: 15.12 .2020

\begin{abstract}
Objective: Nanotechnology is an emerging technology which has wide applications in many fields. Prime concern of research in nanotechnology is the synthesis of nano-material with the controlled size and shape. Recently, biosynthesis of metallic nano-particles has gained popularity owing to its eco-friendliness. The increasing use of copper nanoparticles (CNPs) in medicine and industry demands an understanding of their potential toxicities.

Methods: Genotoxicity of CNPs was assessed using the in vitro micronucleus assay which is standard genotoxicity assay. In this study, CNP was tested in the absence and presence of the metabolic activation ( $2 \% \mathrm{v} / \mathrm{v}$ S9 mix). Human peripheral blood lymphocyte cultures were exposed to CNPs, at 5 dose-levels between 0.125 to $2 \mu \mathrm{L} / \mathrm{mL}$ of culture medium in absence and presence of the metabolic activation system.

Results: Required level of cytotoxicity ( $55 \pm 5 \%$ reduction in replicative index, i.e., cytostasis) was observed in absence of the metabolic activation at the test concentration of $2 \mu \mathrm{L} / \mathrm{mL}$. Therefore, dose levels selected for scoring of binucleated cells containing micronuclei were: $0.5,1$, and $2 \mu \mathrm{L} / \mathrm{mL}$. From the obtained data of MNBN cells (Binucleated cells with micronuclei) for all three selected test concentration was found in the range of negative and vehicle control.

Conclusion: Our results concluded that, CNPs did not induce statistically significant or biologically relevant increase in number of binucleated cells with micronuclei in absence and presence of the metabolic activation.
\end{abstract}

Keywords: Metal nanoparticles, micronucleus test, genotoxicity, lymphocytes.

\section{INTRODUCTION}

The use of nanomaterials (size between $1 \mathrm{~nm}$ and 100 $\mathrm{nm}$ ) in the world has become an important component of consumer products in recent years. This fact has gradually led to an increase in concerns and debates about the impact of nanomaterials on different biological systems $(1,2)$. According to assessments in recent years, engineered metal nanoparticles, which have small size, large specific surface area and surface reactivity, are extensively used in many industries such as electronic, textile, cosmetic, pharmacology, and medicine (1). Because of their unique properties, NPs may be useful in a diverse range of applications, such as the biomedical field, the use of nano vaccines and nano drugs. (3). Hence, nanoparticles increased use enhances the risk of its exposure to humans and other living organisms. These risks may cause cytotoxic, genotoxic, and biochemically adverse effects on the biological systems. Therefore, there is an urgent need to eliminate these adverse effects of nanoparticles on biological systems. Because of the increasing evidence of adverse effect nanoparticles on biological systems, scientists became concerned to eliminate this effect. As a result, studies on the possible adverse effects of nanoparticles, especially genotoxicity, have increased (4). Some tests, including the micronucleus test, comet assay, and gamma $\mathrm{H} 2 \mathrm{AX}$, are commonly used to assess the genotoxicity of many different chemicals (drug, pesticide, NPs, and phthalates) in vivo as well as in vitro studies (5). The in vitro micronucleus test is a standard test for evaluation of genotoxicity. It is simple, useful, and applicable in different cell types. The type performed using cytochalasin B is the most useful micronucleus assay which produces binucleated cells (BNCs) (6).

Genotoxic effects of different types of nanoparticles have been evaluated by several researchers (7-9). Shukla et al. investigated titanium dioxide $\mathrm{NPs}$ ( $\mathrm{TiO}_{2} \mathrm{NPs}$ ) in human epidermal cells which cause reactive oxygen species (ROS) mediated genotoxicity (10). 
In the present study, CNPs was tested in the absence and presence of the metabolic activation ( $2 \% \mathrm{v} / \mathrm{v}$ S9 mix). Human peripheral blood lymphocyte cultures were exposed to CNPs, at 5 dose-levels (two cultures/dose level) between 0.125 to $2 \mu \mathrm{L} / \mathrm{mL}$ of culture medium in absence and presence of the metabolic activation system.

\section{METHODS}

\subsection{Materials}

Mallotus phillipensis were collected from the Botanical Garden of Navsari Agriculture University (N.A.U.), Navsari. Their botanical identification and authentication was done by the authorities of the Herbarium of N.A.U. Copper (II) sulfate pentahydrate salt-CuSO $5_{4} \mathrm{H}_{2} \mathrm{O}$ (Loba Chemie), DMSO (Finar), Methanol (Finar) was purchased. Positive controls such as Vinblastine and Cyclophosphamide, RPMI 1640 medium, $\beta$ - NADP, D-Glucose-6-phosphate, Cytochalasin-B and Potassium chloride were purchased from Sigma-Aldrich (St. Louis, USA). All other chemicals used in the experiments were also purchased from Qualigens. Giemsa Powder used in the experiment was purchased from Merck. The S9 fraction procured from Dr. G. P. Meshram, Nagpur (MWR/ARI/ S9F/01/17. Sep 2017) was used in this assay. Fetal Bovine Serum and $2 \%$ Phytohaemagglutinin were procured from Gibco.

\subsection{Synthesis of Copper Nanoparticles}

Copper ions can be reduced to nanosize by using reducing agent. In this study methanolic extracts of Mallotus phillipensis leaves were used as a reducing agent. For copper nanoparticles synthesis, $10 \mathrm{~mL}$ leaf extract of Mallotus phillipensis was added to $100 \mathrm{~mL}$ of $1 \mathrm{mM}$ aqueous copper sulphate solution in a $250 \mathrm{~mL}$ Erlenmeyer flask. The flask was then kept overnight at room temperature. The green colored copper nanoparticles solution thus obtained was purified by repeated centrifugation at 12000 RPM for 15 minutes followed by re-dispersion of the pellet in ethanol.

\subsection{Characterization Method}

The characterization of the synthesized silver, copper and zinc nanoparticles were carried out using UV-Vis spectrophotometer and Scanning Electron microscope (SEM analysis).

\subsection{Test System}

This study was performed at the Department of Toxicology, Jai Research Foundation, Valvada - 396 105, Dist. Valsad, Gujarat, India.

The test system used for the in vitro mammalian cell micronucleus test was human peripheral blood lymphocytes. The selection criteria for a volunteer were as per JRF standard operating procedure. Blood was drawn from healthy, female volunteer ( 25 years old), by venous puncture using heparinized syringe (Heparin obtained from Biological E. Limited, Hyderabad). A trained medical laboratory technician collected blood by vein puncture using a $23 \mathrm{G}$ needle attached to a $50 \mathrm{~mL}$ disposable syringe.

\subsection{Cytotoxicity}

CNPs was evaluated for its potential to induce micronuclei at the tested concentrations of $0.125,0.25,0.5,1$ and $2 \mu \mathrm{L}$ $\mathrm{CNPs} / \mathrm{mL}$ of culture medium in the absence and presence ( $2 \% \mathrm{v} / \mathrm{v}$ S9) of a metabolic activation.

\subsection{Lymphocyte Isolation and Exposure to Test}

Whole blood was cultured in RPMI-1640 (Roswell Park Memorial Institute) with L-glutamine and $25 \mathrm{~mm}$ HEPES containing antibiotics and antimycotic solution (penicillin: 50 $\mathrm{IU} / \mathrm{mL}$; streptomycin: $50 \mu \mathrm{g} / \mathrm{mL}$ and amphotericin B: $0.25 \mu \mathrm{g} /$ $\mathrm{mL}$ ) supplemented with $20 \%$ heat-inactivated $\left(56^{\circ} \mathrm{C}\right.$; 30 min.) fetal bovine serum. Cultures were prepared separately in a centrifuge tube containing heparin sodium. Each contained $0.5 \mathrm{~mL}$ of whole blood in $9.5 \mathrm{~mL}$ of complete medium [containing $20 \%$ heat-inactivated $\left(56^{\circ} \mathrm{C}\right.$; $30 \mathrm{~min}$.) fetal bovine serum and $2 \%$ Phytohemagglutinin (PHA-M)] in centrifuge tubes and incubated at $37 \pm 1^{\circ} \mathrm{C}$ and $5 \% \mathrm{CO}_{2}$ in a $\mathrm{CO}_{2}$ incubator for approximately 48 hours. Same procedure was used for preparation of cultures for all the phases of the experiments.

Peripheral blood lymphocyte cultures are exposed to the test item both in the absence and presence of metabolic activation. The actin polymerization inhibitor, Cytochalasin B, is added to block cytokinesis, resulting in binucleated cells. After exposure to the test item, the cells are grown for a period sufficient to allow chromosome or spindle damage to lead to the formation of micronuclei in interphase cells and for the induction of aneuploidy. At predetermined intervals, cells are treated with Cyto-B, harvested, stained and interphase cells are analyzed microscopically for the presence of micronuclei.

The main study was conducted in two phases with lymphocytes exposed for $4 \mathrm{~h}$ (hour) without and with metabolic activation ( $2 \%$ v/v S9) in Phase I and for approx. 24 h exposure without S9 in Phase II. There were two replicates for each treatment concentration including positive, vehicle (DMSO) and negative (untreated control) controls.

Phase I (Absence and presence ( $2 \%$ v/v S9 mix) of metabolic activation and exposure for $4 \mathrm{~h}$ ): In Phase I, the cultures were exposed to the concentrations of $0.125,0.25,0.5,1$ and 2 $\mu \mathrm{L} \mathrm{CNPs} / \mathrm{mL}$ of culture in the absence and presence $(2 \% \mathrm{v} / \mathrm{v}$ S9) of a metabolic activation. For treatment, the first stock solution (stock $A$ ) of the test item was prepared by suspending $400 \mu \mathrm{L}$ of test item in DMSO and made up to $2 \mathrm{~mL}(200 \mu \mathrm{L}$ / $\mathrm{mL}$ ). A volume of $1 \mathrm{~mL}$ of stock $A$ was added to $1 \mathrm{~mL}$ DMSO to obtain $100 \mu \mathrm{L} / \mathrm{mL}$ (stock B). Further stock solutions of 50 $\mu \mathrm{L} / \mathrm{mL}$ (stock C), $25 \mu \mathrm{L} / \mathrm{mL}$ (stock D), and $12.5 \mu \mathrm{g} / \mathrm{mL}$ (stock E) were prepared by serial dilution using $1 \mathrm{~mL}$ of relevant stock with $1 \mathrm{~mL}$ of DMSO. A concurrent negative control (untreated control) and vehicle control (dimethyl sulfoxide) were also 
maintained. Volumes of $180 \mu \mathrm{L}$ of relevant stock solutions of A-E were added into $17.82 \mathrm{~mL}$ of medium to obtain required test concentrations in the absence of metabolic activation.

A volume of $8 \mathrm{~mL}$ of this treatment medium was used for treatment of the respective replicate culture tube. Same procedure was followed for treatment in all phases of the main study. Serum free medium with $\mathrm{KCl}$ was used in the absence of metabolic activation while medium with $\mathrm{S} 9 \mathrm{mix}$ was used in the presence of metabolic activation. The cultures were exposed for $4 \mathrm{~h}$ both in the absence and presence of metabolic activation. At the end of the treatment, cultures were centrifuged at approximately $1500 \mathrm{rpm}$ for 8 minutes and the supernatant was replaced with fresh complete medium containing cytochalasin B $(6 \mu \mathrm{g} / \mathrm{mL})$ and incubated at $37 \pm 1{ }^{\circ} \mathrm{C}$ and $5 \% \mathrm{CO}_{2}$ in a $\mathrm{CO}_{2}$ incubator till harvesting.

The cells were harvested and processed for slide preparation approximately after $24 \mathrm{~h}$ from the beginning of treatment.

Phase II (Absence of metabolic activation and exposure for approximately $24 \mathrm{~h}$ ): In Phase II, the cultures were exposed to the concentrations of $0.125,0.25,0.5,1$ and $2 \mu \mathrm{L} \mathrm{CNPs} / \mathrm{mL}$ of culture (supplemented with 10\% FBS), for approximately $24 \mathrm{~h}$ without $\mathrm{S} 9$ in the absence of metabolic activation with cytochalasin B $(6 \mu \mathrm{g} / \mathrm{mL})$. The cells were harvested and processed for preparation of slides after the exposure period.

As the phase II experiment was performed to confirm the negative results obtained in the absence of metabolic activation in Phase I, slide scoring data were evaluated after evaluating the data of phase I experiment.

Controls: A concurrent negative control (untreated control), vehicle control (dimethyl sulfoxide) and positive controls were maintained, in duplicate, along with each phase of the experiment (except positive control in phase I in absence of S9), both in the absence and presence of metabolic activation, which demonstrate both the activity of the metabolic activation system and the responsiveness of the test system. Cyclophosphamide ( $30 \mu \mathrm{g} / \mathrm{mL}$, Phase I) was used as the positive control in the presence of metabolic activation and Vinblastine $(0.008 \mu \mathrm{g} / \mathrm{mL})$ was used as the positive control in the absence of metabolic activation (Phase II).

\subsection{Harvesting of Cells}

Each culture was harvested and processed separately for the preparation of slides for micronuclei frequency evaluation. Cells were hypotonically treated with cold $(2-8 \stackrel{\circ}{\circ})$ potassium chloride solution $(0.075 \mathrm{M} \mathrm{KCl})$ and centrifuged immediately for 8 minutes. Supernatant was removed and replaced with chilled Carnoy's fixative and centrifuged for 8 minutes. Cells were given further 2 changes of chilled Carnoy's fixative washing.

\subsection{Slide Preparation}

Slides were prepared from each culture tube by pouring approximately $0.5 \mathrm{~mL}$ of the fixed cell suspension, drop by drop on two, pre-cleaned, ice-chilled slides. The slides were dried over a slide warmer and labelled with study number, treatment code, absence/presence metabolic activation and slide number. Two slides were prepared per replicate of culture at each test concentration, Out of these two slides, one was used for scoring and the other served as reserve or used for scoring wherever required. The dried slides were stained with $5 \%$ Giemsa in phosphate buffer for 30 minutes. The slides were made permanent by mounting a cover slip with DPX mountant. In order to prevent bias in the scoring procedure for micronuclei, the slide numbers were masked with code numbers provided by Department of Biostatistics and Systems Information, JRF. All slides were coded before microscopic scoring and decoded after scoring.

\subsection{Scoring of Slides}

\subsubsection{Replicative Index}

All slides, including those of positive, negative control (untreated control) and vehicle control (dimethyl sulfoxide), were independently coded prior to microscopic analysis for replicative index (during main study) and cells with micronuclei (during main study). The slides were examined under a microscope and a minimum number of 500 cells per slide (culture) were counted and numbers of binucleated cells, multi nucleated cells and mono nucleated cells were recorded in different fields to determine the replicative index by using the following formula:

$[($ No. binucleated cells $)+(2 \times$ No. multinucleated cells $)] \div$ (Total number of cells) $\mathrm{T}$

$\mathrm{RI}=-------------------100$

$[($ No. binucleated cells $)+(2 \times$ No. multinucleated cells $)] \div$ (Total number of cells) $\mathrm{C}$

$\%$ Cytostasis $=100-$ Replicative index

Key: $R I=$ Replicative index, $T=$ Treated cultures and $C=$ Control cultures

\subsubsection{Micronucleus Frequency}

Two replicate slides per concentration were used for screening of micronucleated binucleated cells whereas the other two slides were kept in reserve, for scoring whenever required (if binucleated cell frequency is less). The slides were examined for the presence of micronuclei in binucleated cells under a microscope. A minimum of 2000 binucleated cells were screened per concentration to evaluate the incidence of micronuclei. The masked labels were removed and all the slides were decoded after scoring.

\subsection{Statistical Analysis}

Data on micronuclei containing binucleated cells were subjected to Shapiro-Wilk's test for normality and Bartlett's test to assess homogeneity of variance before conducting Analysis of Variance (ANOVA) and Dunnett's t-test (11). Where the data did not meet suitable homogeneity of 
variance, Student's t-test was performed followed by chisquare to determine the level of significance between vehicle control, three selected test concentrations (selected based on the replicative index data) and positive controls.

\section{RESULTS}

\subsection{Synthesis of Copper Nanoparticles}

After 24 hours of reaction, the appearance of greenish colour in the reaction vessels suggests the formation of CNPs. The colour tone of the reaction mixture changes from light blue to greenish indicates the reduction of $\mathrm{Cu}^{++}$ions leads to the formation of CNPs (Figure 1). Different colour change observed in the reaction vessel is due to an effect called Localized Surface Plasmon Resonance.

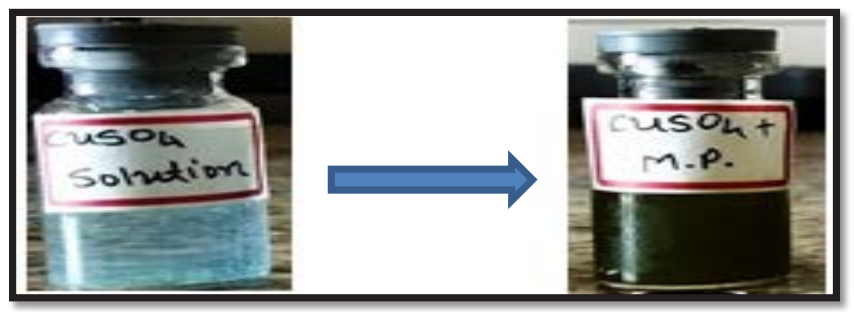

Figure 1. Biosynthesis of Copper nanoparticles using Mallotus phillipensis

\subsection{Characterization of Copper Nanoparticles}

The UV-Vis spectra of CNPs biosynthesized using Mallotus phillipensis was shown in Figure 2. The absorption peak of the prepared CNPs was found around $524 \mathrm{~nm}$ of UV-Vis range, which is characteristic range of copper. CNPs biosynthesized from Mallotus phillipensis have approx. particle size between $\sim 41-50 \mathrm{~nm}$ (Figure 2).

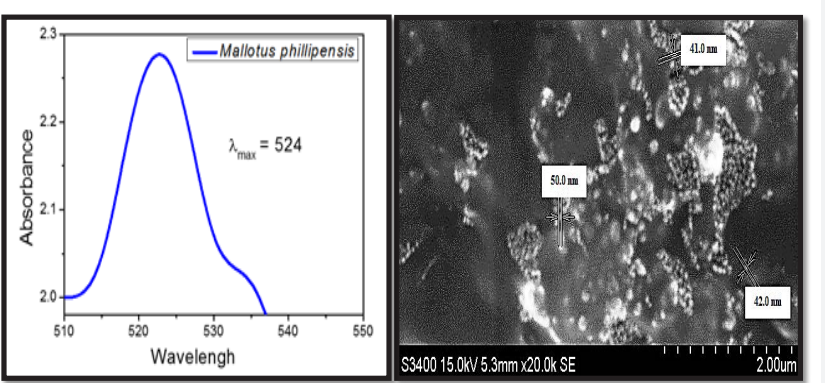

Figure 2. UV-Vis Spectra and SEM Images of Copper Nanoparticles Prepared Using Mallotus Phillipensis

\subsection{Solubility, Precipitation, $\mathrm{pH}$ and Osmolality Tests}

CNPs was insoluble in distilled water, while found to form suspension at $2 \mu \mathrm{L} / \mathrm{mL}$ in dimethyl sulfoxide. The solubility limit for final stock concentration of $200 \mu \mathrm{L} C N P s / m L$, was achieved in DMSO. Therefore dimethyl sulfoxide was selected as the suitable vehicle in this study.
No significant change in $\mathrm{pH}$ ( \pm 1 unit) or osmolality ( $\geq 50 \mathrm{mOsm} /$ $\mathrm{kg} \mathrm{H} 2 \mathrm{O}$ ) were observed in the tested concentrations 0.0625 , $0.125,0.25,0.5,1$, and $2 \mu \mathrm{L} / \mathrm{mL}$ of culture medium, at $0 \mathrm{~h}$ and $4 \mathrm{~h}$. In addition, no precipitation was observed up to the test concentration level $200 \mu \mathrm{L} / \mathrm{mL}$. Therefore, $2 \mu \mathrm{L} / \mathrm{mL}$ was selected as the highest concentration to be tested in the cytotoxicity test.

\subsection{Cytotoxicity}

The $\mathrm{pH}$ and osmolality at the beginning of the treatment at concentration of $2 \mu \mathrm{L} / \mathrm{mL}$ in absence of the metabolic activation system were 7.33 and $442 \mathrm{mOsm} / \mathrm{kg} \mathrm{H}_{2} \mathrm{O}$, respectively (compared to 7.36 and $441 \mathrm{mOsm} / \mathrm{kg} \mathrm{H}_{2} \mathrm{O}$ in the vehicle control). At the same concentration, but in presence ( $2 \% \mathrm{v} / \mathrm{v}$ S9 $\mathrm{mix}$ ) of the metabolic activation system, the $\mathrm{pH}$ and osmolality were 7.33 and $445 \mathrm{mOsm} / \mathrm{kg} \mathrm{H}_{2} \mathrm{O}$, respectively (compared to 7.35 and $444 \mathrm{mOsm} / \mathrm{kg} \mathrm{H}_{2} \mathrm{O}$ in the vehicle control). No relevant influence of the test item on $\mathrm{pH}$ value or osmolality was observed in absence (Phase I and II) and presence of the metabolic activation (Phase I).

Phase I (Absence and presence of the metabolic activation ( $2 \% \mathrm{v} / \mathrm{v}$ S9 $\mathrm{mix}$ ) and exposure for $4 \mathrm{~h}$ ): The cytostasis observed was $1.70,7.29,5.02,8.14$ and $12.17 \%$ at the tested concentration level of $0.125,0.25,0.5,1$, and $2 \mu \mathrm{L}$ CNPs/ $\mathrm{mL}$ in absence of the metabolic activation, respectively. The cytostasis observed in presence of the metabolic activation was $7.13,4.56,5.91,9.64,15.37 \%$ at the tested concentrations of $0.125,0.25,0.5,1$, and $2 \mu \mathrm{L} \mathrm{CNPs/mL}$, respectively. The cytostasis observed for positive control in presence of the metabolic activation was $10.92 \%$. The cytostasis of cultures treated with various concentrations of CNPs, with the positive, negative (untreated control) and vehicle (dimethyl sulfoxide) controls in absence and presence of the metabolic activation (Phase I) is provided in Table 1.

Cytostasis, i.e., reduction in replicative index of $12.17 \%$ and $15.37 \%$ was observed at the tested concentration of $2 \mu \mathrm{L} / \mathrm{mL}$ in absence and presence of the metabolic activation system. Therefore, test concentration levels selected for scoring of binucleated cells containing micronuclei were: $0.5,1$, and $2 \mu \mathrm{L} / \mathrm{mL}$ culture medium in absence and presence of the metabolic activation.

Both in absence and presence of the metabolic activation, CNPs did not induce any statistically significant or biologically relevant increase in number of binucleated cells with micronuclei.

Phase II (Absence of metabolic activation and exposure for 24 h): The cytostasis observed was 5.77, 8.05, 11.23, 14.12 and $40.03 \%$ at the tested concentration levels of $0.125,0.25,0.5$, 1 , and $2 \mu \mathrm{L}$ of CNPs in absence of the metabolic activation, respectively. The cytostasis observed was $10.57 \%$ in the cultures treated with positive control in absence of the metabolic activation. Required level of cytotoxicity (55 $\pm 5 \%$ reduction in replicative index, i.e., cytostasis) was observed in absence of the metabolic activation at the test concentration of $2 \mu \mathrm{L} /$ $\mathrm{mL}$. Therefore dose levels selected for scoring of binucleated cells containing micronuclei were: $0.5,1$, and $2 \mu \mathrm{L} / \mathrm{mL}$. The cytostasis of cultures treated with various concentration levels of CNPs, with the positive, negative (untreated control), and 
vehicle (dimethyl sulfoxide) controls in absence (Phase II) of the metabolic activation are also presented in Table 1.

Table 1. Summary of Cytostasis for Main Study

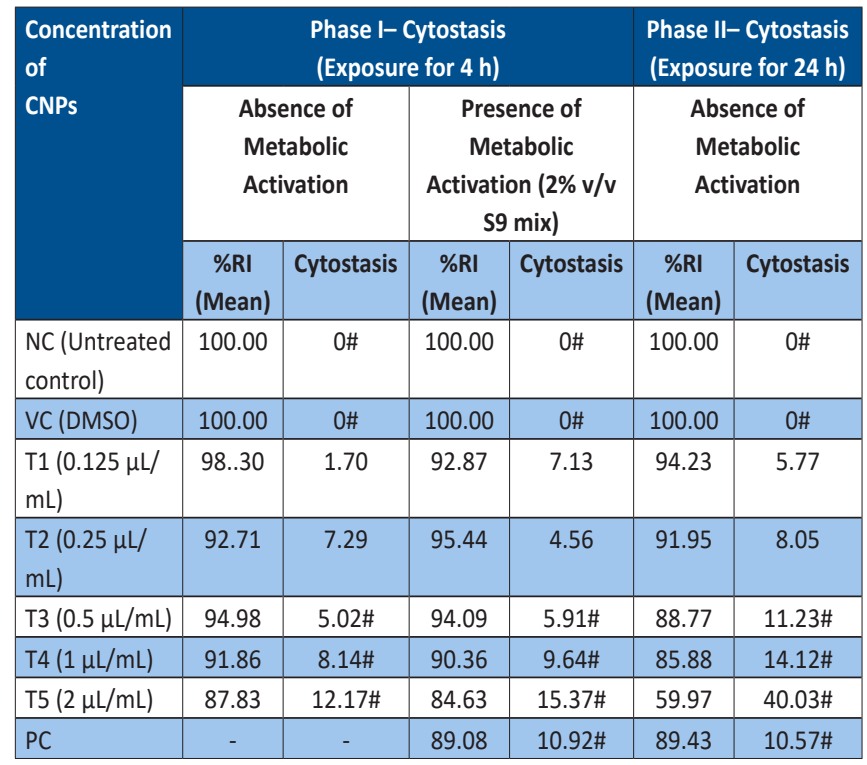

NC: negative control; VC: vehicle control; R: replicate; DMSO: dimethyl sulfoxide; T: treatment group, PC: positive control (Cyclophosphamide @ $30 \mu \mathrm{g} / \mathrm{mL}$ in the presence of metabolic activation for Phase I and Vinblastine @ $0.008 \mu \mathrm{g} / \mathrm{mL}$ in the absence of metabolic activation for Phase II); \#: concentrations selected for scoring of binucleated cells containing micronuclei; Rl: replicative index

Replicative index and micronucleus frequency check (Figure 3) results of negative and vehicle control were comparable and no adverse effect of DMSO was observed on cultures when compared with that of the concurrent negative control (untreated control) during the main study. Individual observation for replicative index of cultures treated with various concentration levels of CNPs, with the positive, negative (untreated control), and vehicle (dimethyl sulfoxide) controls in absence (Phase I and Phase II) and presence (Phase I) of the metabolic activation are presented in Table 2, Table 4 and Table 3, respectively.

In absence of the metabolic activation, CNPs did not induce any statistically significant or biologically relevant increase in the number of binucleated cells with micronuclei.

The number of binucleated cells with micronuclei found in the negative and vehicle control cultures were within the published range and acceptable for addition into laboratory's historical data base (12). The positive controls, vinblastine produced statistically significant increase in the frequency of micronuclei containing binucleated cells in phase II (continuous treatment) in absence of the metabolic activation and cyclophosphamide in Phase I in presence of the metabolic activation (short term exposure). Response of the positive controls demonstrated the efficiency of the test system and suitability of the test procedures and conditions employed in the study.

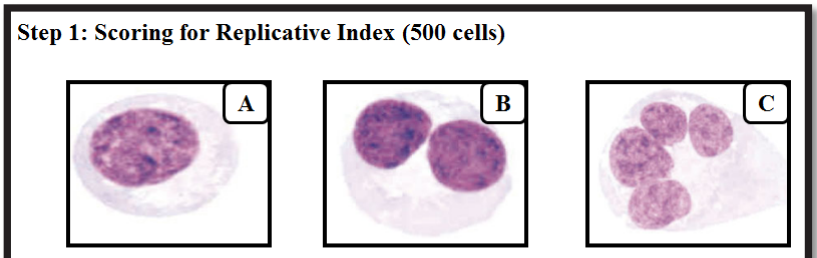

Step 2: Scoring for Micronucleus Frequency (1000 cells)

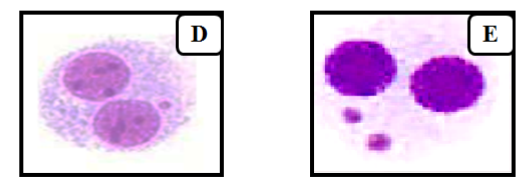

Figure 3. Photomicrographs of Mononucleated Cell (A), Binucleated Cell (B), Multinucleated Cell (C), Micronuclei Containing Binucleated Cell $(D-E)$

Table 2. Individual Observation for Replicative Index - Phase I (Absence of Metabolic Activation)

\begin{tabular}{|c|c|c|c|c|c|}
\hline $\begin{array}{l}\text { Concentration of } \\
\text { CNPs }\end{array}$ & Replicate & No. of Mononucleated Cells & No. of Binucleated Cells Scored & No. of Multinucleated Cells & Total No. of Cells \\
\hline \multirow{2}{*}{ NC (Untreated Control) } & R1 & 143 & 334 & 56 & 533 \\
\hline & R2 & 119 & 325 & 78 & 522 \\
\hline \multirow{2}{*}{ VC (DMSO) } & R1 & 146 & 301 & 79 & 526 \\
\hline & R2 & 139 & 328 & 51 & 518 \\
\hline \multirow{2}{*}{$\mathrm{T} 1(0.125 \mu \mathrm{L} / \mathrm{mL})$} & R1 & 152 & 300 & 80 & 532 \\
\hline & R2 & 141 & 348 & 40 & 529 \\
\hline \multirow{2}{*}{$\mathrm{T} 2(0.25 \mu \mathrm{L} / \mathrm{mL})$} & R1 & 167 & 323 & 40 & 530 \\
\hline & R2 & 146 & 332 & 50 & 528 \\
\hline \multirow{2}{*}{ T3 $(0.5 \mu \mathrm{L} / \mathrm{mL})$} & R1 & 156 & 329 & 51 & 536 \\
\hline & R2 & 148 & 327 & 50 & 525 \\
\hline \multirow{2}{*}{$\mathrm{T} 4(1 \mu \mathrm{L} / \mathrm{mL})$} & R1 & 167 & 306 & 52 & 525 \\
\hline & R2 & 162 & 310 & 49 & 521 \\
\hline \multirow{2}{*}{$\mathrm{T} 5(2 \mu \mathrm{L} / \mathrm{mL})$} & R1 & 171 & 305 & 38 & 514 \\
\hline & R2 & 169 & 316 & 40 & 525 \\
\hline
\end{tabular}

R: replicate; T: treatment group; NC: negative control; VC: vehicle control; DMSO: dimethyl sulfoxide 
Summaries of percent Micronuclei Containing binucleated cells are provided in Table 5 for phase I and II. Individual observations of Micronuclei Containing binucleated cells and binucleated cells of Phase I and II with individual values are provided in Table 6.
Student's t-test was performed for statistical significance between two groups. The $P$ value is $\leq 0.01$ ( $1 \%$ level) is accepted as significant. Summaries of statistical significance of $P$ value are provided in Table 7 .

Table 3. Individual Observation for Replicative Index - Phase I [Presence of Metabolic Activation (2\% v/v S9 mix)]

\begin{tabular}{|c|c|c|c|c|c|}
\hline Concentration of CNPs & Replicate & $\begin{array}{c}\text { No. of } \\
\text { Mononucleated Cells }\end{array}$ & $\begin{array}{l}\text { No. of Binucleated } \\
\text { Cells Scored }\end{array}$ & $\begin{array}{c}\text { No. of } \\
\text { Multinucleated Cells }\end{array}$ & Total No. of Cells \\
\hline \multirow{2}{*}{ NC (Untreated Control) } & R1 & 112 & 319 & 99 & 530 \\
\hline & R2 & 141 & 332 & 63 & 536 \\
\hline \multirow{2}{*}{ VC (DMSO) } & R1 & 147 & 306 & 93 & 546 \\
\hline & R2 & 124 & 331 & 76 & 531 \\
\hline \multirow{2}{*}{$\mathrm{T} 1(0.125 \mu \mathrm{L} / \mathrm{mL})$} & R1 & 140 & 309 & 59 & 508 \\
\hline & R2 & 137 & 316 & 56 & 509 \\
\hline \multirow{2}{*}{$\mathrm{T} 2(0.25 \mu \mathrm{L} / \mathrm{mL})$} & R1 & 134 & 313 & 70 & 517 \\
\hline & R2 & 139 & 319 & 62 & 520 \\
\hline \multirow{2}{*}{$\mathrm{T} 3(0.5 \mu \mathrm{L} / \mathrm{mL})$} & R1 & 118 & 358 & 58 & 534 \\
\hline & R2 & 145 & 328 & 49 & 522 \\
\hline \multirow{2}{*}{$\mathrm{T} 4(1 \mu \mathrm{L} / \mathrm{mL})$} & R1 & 142 & 311 & 52 & 505 \\
\hline & R2 & 146 & 321 & 50 & 517 \\
\hline \multirow{2}{*}{$\mathrm{T} 5(2 \mu \mathrm{L} / \mathrm{mL})$} & R1 & 162 & 319 & 35 & 516 \\
\hline & R2 & 151 & 321 & 38 & 510 \\
\hline \multirow{2}{*}{ PC } & R1 & 135 & 362 & 38 & 535 \\
\hline & R2 & 144 & 351 & 35 & 530 \\
\hline
\end{tabular}

PC: positive control (Cyclophosphamide $30 \mu \mathrm{g} / \mathrm{mL}$ in the presence of metabolic activation)

Table 4. Individual Observation for Replicative Index - Phase II (Absence of Metabolic Activation)

\begin{tabular}{|c|c|c|c|c|c|}
\hline Concentration of CNPs & Replicate & $\begin{array}{l}\text { No. of Mononucleated } \\
\text { Cells }\end{array}$ & $\begin{array}{l}\text { No. of Binucleated } \\
\text { Cells Scored }\end{array}$ & $\begin{array}{c}\text { No. of } \\
\text { Multinucleated Cells }\end{array}$ & Total No. of Cells \\
\hline \multirow{2}{*}{ NC (Untreated Control) } & R1 & 134 & 342 & 52 & 528 \\
\hline & R2 & 140 & 335 & 56 & 531 \\
\hline \multirow{2}{*}{ VC (DMSO) } & R1 & 153 & 355 & 23 & 531 \\
\hline & R2 & 119 & 333 & 76 & 528 \\
\hline \multirow{2}{*}{$\mathrm{T} 1(0.125 \mu \mathrm{L} / \mathrm{mL})$} & R1 & 141 & 325 & 39 & 505 \\
\hline & R2 & 146 & 327 & 34 & 507 \\
\hline \multirow{2}{*}{$\mathrm{T} 2(0.25 \mu \mathrm{L} / \mathrm{mL})$} & R1 & 160 & 305 & 39 & 504 \\
\hline & R2 & 157 & 316 & 43 & 516 \\
\hline \multirow{2}{*}{ T3 $(0.5 \mu \mathrm{L} / \mathrm{mL})$} & R1 & 161 & 305 & 35 & 501 \\
\hline & R2 & 165 & 309 & 32 & 506 \\
\hline \multirow{2}{*}{$\mathrm{T} 4$ (1 $\mu \mathrm{L} / \mathrm{mL})$} & R1 & 171 & 305 & 32 & 508 \\
\hline & R2 & 176 & 299 & 30 & 505 \\
\hline \multirow{2}{*}{$\mathrm{T} 5(2 \mu \mathrm{L} / \mathrm{mL})$} & R1 & 280 & 205 & 21 & 506 \\
\hline & R2 & 278 & 198 & 32 & 508 \\
\hline \multirow{2}{*}{ PC } & R1 & 147 & 327 & 33 & 507 \\
\hline & R2 & 169 & 305 & 29 & 503 \\
\hline
\end{tabular}

R: replicate; T: treatment group; NC: negative control; VC: vehicle control; DMSO: dimethyl sulfoxide; PC: positive control (Vinblastine $0.008 \mu \mathrm{g} / \mathrm{mL}$ in the absence of metabolic activation) 
Table 5. Summary of Mean Binucleated Cells, Micronuclei Containing Binucleated Cells and Percent Micronuclei Containing Binucleated Cells

\begin{tabular}{|c|c|c|}
\hline \multirow{3}{*}{$\begin{array}{l}\text { Concentration of } \\
\text { CNPs }\end{array}$} & \multicolumn{2}{|c|}{ Phase I [Absence of Metabolic Activation] } \\
\hline & MNBN Cells & $\%$ MNBN Cells \\
\hline & Mean \pm SD & Mean \pm SD \\
\hline NC (Untreated Control) & $3.00 \pm 1.41$ & $0.30 \pm 0.14$ \\
\hline VC ( DMSO) & $3.50 \pm 0.71$ & $0.35 \pm 0.07$ \\
\hline $\mathrm{T} 3(0.5 \mu \mathrm{L} / \mathrm{mL})$ & $2.00 \pm 1.41$ & $0.20 \pm 0.14$ \\
\hline $\mathrm{T} 4(1 \mu \mathrm{L} / \mathrm{mL})$ & $2.50 \pm 0.71$ & $0.25 \pm 0.07$ \\
\hline $\mathrm{T} 5(2 \mu \mathrm{L} / \mathrm{mL})$ & $2.00 \pm 1.41$ & $0.20 \pm 0.14$ \\
\hline \multirow{3}{*}{$\begin{array}{l}\text { Concentration of } \\
\text { CNPs }\end{array}$} & \multicolumn{2}{|c|}{ Phase I [Presence of Metabolic Activation (2\% v/v S9 mix)] } \\
\hline & MNBN Cells & $\%$ MNBN Cells \\
\hline & Mean \pm SD & Mean \pm SD \\
\hline NC (Untreated Control) & $2.50 \pm 0.71$ & $0.25 \pm 0.07$ \\
\hline VC ( DMSO) & $3.00 \pm 1.41$ & $0.30 \pm 0.14$ \\
\hline T3 $(0.5 \mu \mathrm{L} / \mathrm{mL})$ & $1.50 \pm 0.71$ & $0.15 \pm 0.07$ \\
\hline $\mathrm{T} 4(1 \mu \mathrm{L} / \mathrm{mL})$ & $2.00 \pm 1.41$ & $0.20 \pm 0.14$ \\
\hline $\mathrm{T} 5(2 \mu \mathrm{L} / \mathrm{mL})$ & $2.50 \pm 0.71$ & $0.25 \pm 0.07$ \\
\hline $\begin{array}{l}\text { PC } \\
\text { (Cyclophosphamide @ } 30 \mu \mathrm{g} / \mathrm{mL} \text { ) }\end{array}$ & $42.00 \pm 1.41$ & $4.17 \pm 0.17$ \\
\hline \multirow{3}{*}{$\begin{array}{l}\text { Concentration of } \\
\text { CNPs }\end{array}$} & \multicolumn{2}{|c|}{ Phase II [Absence of Metabolic Activation] } \\
\hline & MNBN Cells & $\%$ MNBN Cells \\
\hline & Mean \pm SD & Mean \pm SD \\
\hline NC (Untreated Control) & $3.00 \pm 1.41$ & $0.30 \pm 0.14$ \\
\hline VC ( DMSO) & $3.50 \pm 0.71$ & $0.35 \pm 0.07$ \\
\hline $\mathrm{T} 3(0.5 \mu \mathrm{L} / \mathrm{mL})$ & $2.50 \pm 0.71$ & $0.25 \pm 0.07$ \\
\hline $\mathrm{T} 4(1 \mu \mathrm{L} / \mathrm{mL})$ & $2.00 \pm 1.41$ & $0.20 \pm 0.14$ \\
\hline $\mathrm{T} 5(2 \mu \mathrm{L} / \mathrm{mL})$ & $2.50 \pm 0.71$ & $0.25 \pm 0.07$ \\
\hline $\begin{array}{l}\text { PC } \\
\text { (Vinblastine @ } 0.008 \mu \mathrm{g} / \mathrm{mL} \text { ) }\end{array}$ & $44.00 \pm 1.41$ & $4.40 \pm 0.15$ \\
\hline
\end{tabular}

NC: negative control; VC: vehicle control; DMSO: dimethyl sulfoxide; BN cells: binucleated cells; MNBN: micronucleated binucleated cells; SD: standard deviation; PC: positive control; : significantly higher than the control at $1 \%$ level $(p \leq 0.01)$ and : significantly higher than the control at $5 \%$ level $(p \leq 0.05)$

Table 6. Individual Observation of Slides for Frequency of Micronuclei Containing Binucleated Cells

\begin{tabular}{|c|c|c|c|c|c|c|c|c|c|c|c|c|}
\hline \multirow{3}{*}{ 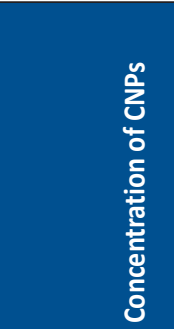 } & \multicolumn{8}{|c|}{ Phase I } & \multicolumn{4}{|c|}{ Phase II } \\
\hline & \multirow[b]{2}{*}{$\mathbf{R}$} & \multicolumn{3}{|c|}{ Absence of Metabolic Activation } & \multirow[t]{2}{*}{$\mathbf{R}$} & \multicolumn{3}{|c|}{$\begin{array}{c}\text { Presence of Metabolic Activation } \\
\text { (2\% v/v S9 mix) }\end{array}$} & \multirow[b]{2}{*}{$\mathbf{R}$} & \multicolumn{3}{|c|}{$\begin{array}{c}\text { Absence of Metabolic } \\
\text { Activation }\end{array}$} \\
\hline & & 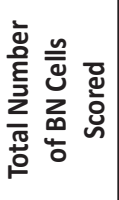 & 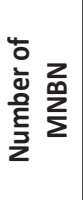 & 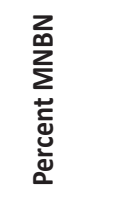 & & 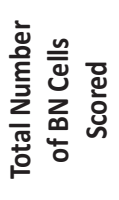 & 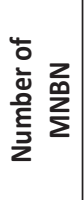 & 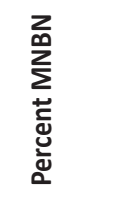 & & 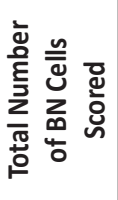 & 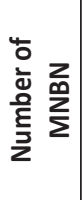 & 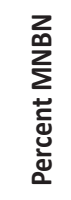 \\
\hline \multirow{2}{*}{$\begin{array}{l}\text { NC (Untreated } \\
\text { Control) }\end{array}$} & 1 & 1004 & 4 & 0.400 & 1 & 1002 & 2 & 0.200 & 1 & 1004 & 2 & 0.200 \\
\hline & 2 & 1015 & 2 & 0.200 & 2 & 1003 & 3 & 0.300 & 2 & 1004 & 4 & 0.400 \\
\hline \multirow{2}{*}{ VC (DMSO) } & 1 & 1002 & 4 & 0.400 & 1 & 1004 & 4 & 0.400 & 1 & 1004 & 3 & 0.300 \\
\hline & 2 & 1003 & 3 & 0.300 & 2 & 1008 & 2 & 0.200 & 2 & 1005 & 4 & 0.400 \\
\hline \multirow{2}{*}{ T3 $(0.5 \mu \mathrm{L} / \mathrm{mL})$} & 1 & 1003 & 3 & 0.300 & 1 & 1004 & 2 & 0.200 & 1 & 1004 & 2 & 0.200 \\
\hline & 2 & 1004 & 1 & 0.100 & 2 & 1003 & 1 & 0.100 & 2 & 1002 & 3 & 0.300 \\
\hline \multirow{2}{*}{$\mathrm{T} 4(1 \mu \mathrm{L} / \mathrm{mL})$} & 1 & 1003 & 2 & 0.200 & 1 & 1004 & 3 & 0.300 & 1 & 1001 & 3 & 0.300 \\
\hline & 2 & 1005 & 3 & 0.300 & 2 & 1004 & 1 & 0.100 & 2 & 1002 & 1 & 0.100 \\
\hline \multirow{2}{*}{ T5 $(2 \mu \mathrm{L} / \mathrm{mL})$} & 1 & 1005 & 1 & 0.100 & 1 & 1014 & 3 & 0.300 & 1 & 1008 & 2 & 0.200 \\
\hline & 2 & 1004 & 3 & 0.300 & 2 & 1006 & 2 & 0.200 & 2 & 1003 & 3 & 0.300 \\
\hline \multirow{2}{*}{ PC } & 1 & \multirow{2}{*}{\multicolumn{3}{|c|}{ NA }} & 1 & 1003 & 43 & 4.290 & 1 & 1001 & 45 & 4.500 \\
\hline & 2 & & & & 2 & 1013 & 41 & 4.050 & 2 & 1003 & 43 & 4.290 \\
\hline
\end{tabular}

R: replicate; T: treatment group; NC: negative control; VC: vehicle control; DMSO: dimethyl sulfoxide; BN cells: binucleated cells; MNBN: micronucleated binucleated cells; PC: positive control (Cyclophosphamide $30 \mu \mathrm{g} / \mathrm{mL}$ in the absence and Vinblastine $0.008 \mu \mathrm{g} / \mathrm{mL}$ in the absence of metabolic activation); NA: not applicable. 
Table 7. Statistical Analysis

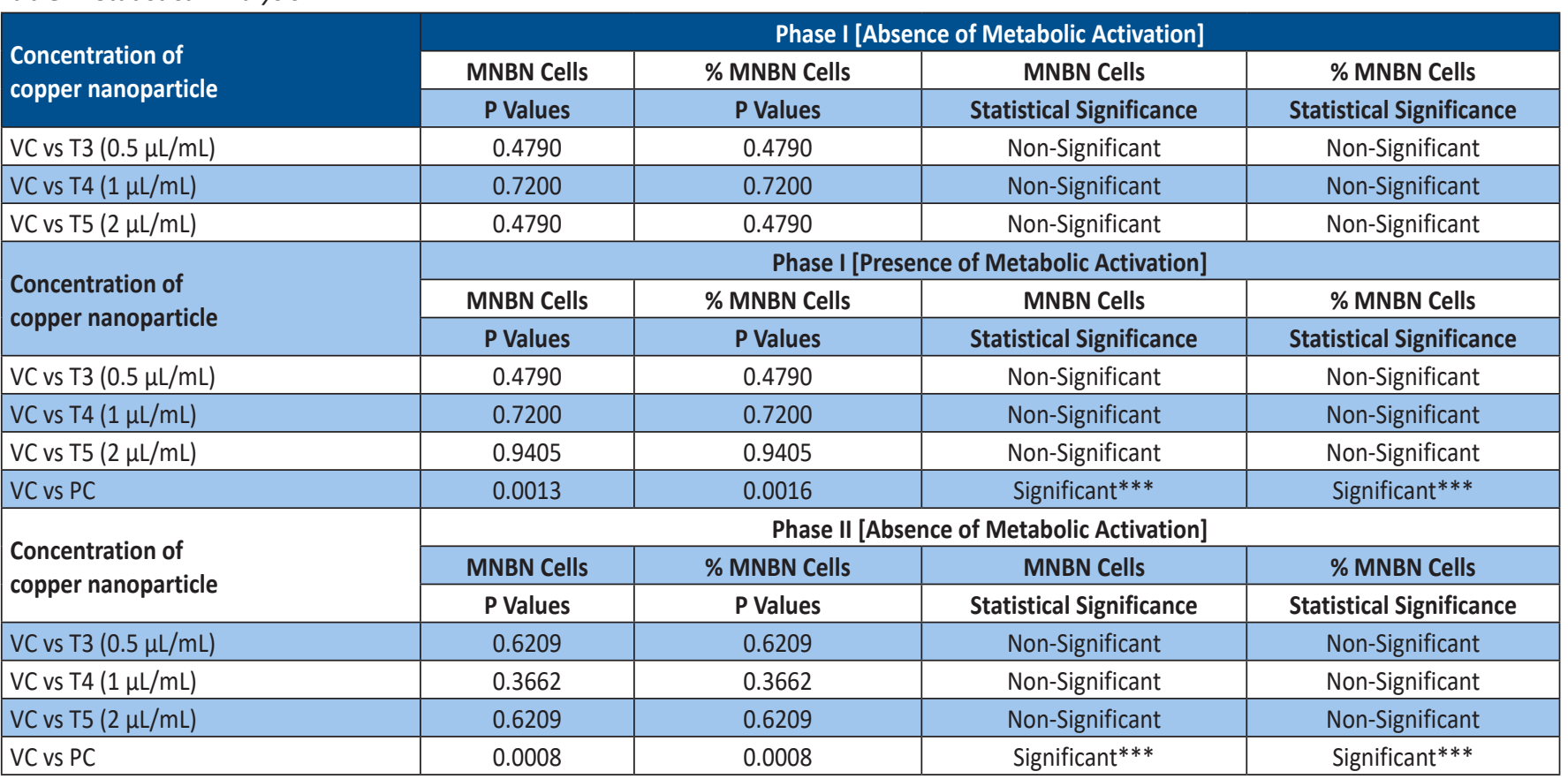

T: treatment group; VC: vehicle control, PC: positive control, MNBN: micronucleated binucleated cells, P value is $\leq 0.01$ (1\% level) is accepted as higher (***) significant

\section{DISCUSSION}

The fast development of nano-products in recent years has made significant concerns about their safety. Nanotoxicity as a new branch of toxicity can be described as the study of the adverse effects of nanomaterials on living organisms and ecosystems. Genotoxicity is a vital aspect of studying the damage to genetic information within a cell.

In this study, genotoxic effect of biosynthesized CNPs was evaluated by using in vitro mammalian micronucleus test. Results of the study indicates that biosynthesized CNPs did not induce any toxic potential to form micronuclei in cultured human peripheral blood lymphocytes up to using $0.125 \mu \mathrm{L}$ / $\mathrm{mL}-2 \mu \mathrm{L} / \mathrm{mL}$ concentration of CNPs.

The genotoxicity of nanoparticles may be affected by the nanoparticle properties, including the composition, size, shape, surface properties, physicochemical specifications $(\mathrm{pH}$, temperature, etc.), solubility and other factors such as the nanoparticle concentration, exposure time, cell type used and treatment regime.

\section{CONCLUSION}

From results of this study, it is concluded that CNPs did not show any potential to induce micronuclei or clastogenic or aneugenic potential in cultured human peripheral blood lymphocytes, both in absence and presence (2\% v/v s9 mix) of the metabolic activation system under the present experimental conditions.

\section{Acknowledgement}

The authors would like to thank the Authorities of Jai Research Foundation, Vapi, Gujarat, India for providing all assistance and support for the timely completion of this research work.

\section{REFERENCES}

[1] Courbiere B, Auffan M, Rollais R, Tassistro V, Bonnefoy A, Botta $A$, Rose J, Orsière Tand Perrin J. Ultra structural Interactions and Genotoxicity Assay of Cerium 20 Dioxide Nanoparticles on Mouse Oocytes. International Journal of Molecular Sciences, 2013; 14(2): 1613-21628. DOI:10.3390/ijms141121613.

[2] Dhawan A and Sharma V. Toxicity assessment of nanomaterials: methods and challenges. Analytical and bioanalytical chemistry, 2010; 398(2):589-605.DOI:10.1007/ s00216.010.3996-x.

[3] Shruti R, Albert $D$ and Andreas L. Interaction of nanoparticles with proteins: relation to bio-reactivity of the nanoparticle. Journal of Nanobiotechnology, 2013; 11: 26. DOI:10.1186/1477-3155-11-26.

[4] Gonzalez L, Lison D and Kirsch-Volders M. Genotoxicity of engineerednanomaterials:acritical review. Nanotoxicology,2008; 2:252-273. DOI: 10.1080/174.353.90802464986.

[5] Balasubramanyam A, Sailaja N, Mahboob M, Rahman M, Hussain $S$ and Grover P. In vitro mutagenicity assessment of aluminium oxide nanomaterials using the Salmonella/ microsome assay. Toxicology in Vitro, 2010; 24:18711876. DOI: 10.1016/j.tiv.2010.07.004.

[6] Battal D, Elik A and Guler G. $\mathrm{SiO}_{2}$ nanoparticle induced sizedependent genotoxicity - an in vitro study using sister chromatid exchange, micronucleus and comet assay. Drug and Chemical Toxicology, 2015; 38: 196-204.DOI: 10.3109/01480.545.2014.928721. 
[7] Asharani P, Hande M and Valiyaveettil S. Anti-proliferative activity of silver nanoparticles. BMC Cell Biology, 2009; 10(1): 1-14. DOI: 10.1186/1471-2121-10-65.

[8] Ghosh M. In vitro and In vivo genotoxicity of silver nanoparticles. Mutation Research, 2012; 749: 60-69. DOI:10.1016/j.mrgentox.2012.08.007.

[9] Kumari M, Mukherjee A and Chandrasekaran N. Genotoxicity of silver nanoparticles in Allium cepa. The Science of the Total Environment, 2009; 407: 5243-5246. DOI:10.1016/j. scitotenv.2009.06.024.
[10] Shukla R, Sharma V, Pandey A, Singh S, Sultana S and Dhawan A. ROS-mediated genotoxicity induced by titanium dioxide nanoparticles in human epidermal cells. Toxicology in Vitro, 2011; 25(1):231-241. DOI:10.1016/j.tiv.2010.11.008.

[11] Gad S.C. and Weil C.S. Statistics for Toxicologists In: Principles and Methods of Toxicology, $3^{\text {rd }}$ Edition, Hayes A.W. [ed.] Raven Press Ltd., New York, 1994; 221-274.

[12] Fenech M. Cytokinesis-block micronucleus cytome assay, Nature Protocols, 2007; 2(5): 1084-1104. DOI:10.1038/ nprot.2007.77

How to cite this article: Patel MH, Vashi KD, Minocheherhomji FP, Nagnae R. Genotoxicity of Plant Mediated Synthesis of Copper Nanoparticles Evaluated Using In Vitro Mammalian Cell Micronucleus Test. Clin Exp Health Sci 2021; 11: 65-73. DOI: 10.33808/ clinexphealthsci.665837 